\title{
Analyzing Demographic Profile of Stall Fed vis-à-vis Extensive Rearing Goat Farmers of Punjab
}

\author{
Aman Deep Singh Dhaliwal ${ }^{1}$, Rajesh Kasrija ${ }^{1 *}$, Parminder Singh ${ }^{1}$, \\ Y.S. Jadoun ${ }^{1}$ and Sandeep Kaswan ${ }^{2}$ \\ ${ }^{1}$ Department of Veterinary and Animal Husbandry Extension Education, ${ }^{2}$ Department of \\ Livestock Production and Management, Guru Angad Dev Veterinary and Animal Sciences \\ University, Ludhiana, India \\ *Corresponding author
}

\begin{abstract}
A B S T R A C T
The present study was conducted in all the six different agro-climatic zones of Punjab to analyze the demographic profile of stall fed vis-à-vis extensive rearing goat farmers. Most of goat farmers of Group I (Stall fed) and Group II (Extensive/Grazing) were in age group of 31-60 years, followed by $\leq 30$ years and then $>60$ years. All the goat farmers were male. The education level of Group I goat farmers is more than Group II. However, most of the farmers of Group II in different zones were illiterate. Goat farmers in both type of rearing system are primarily surviving on goat farming, indicating the importance of adopting goat farming as main occupation instead of subsidiary occupation or side business. A large number of goat farmers in Group I, II and in overall Punjab were having medium and large families with predominant family type as Joint family; were landless. Large number of Group I, Group II and overall Punjab goat farmers belonged to Schedule caste, Backward caste and other backward caste. Different demographic parameters are inter-correlated at $\mathrm{P}<0.01$ level for Group I; and at $\mathrm{P}<0.05$ level and $\mathrm{P}<0.01$ level for Group II goat farmers. The present study highlights demographic details and the interrelationship between different demographic parameters, which can be utilized while planning extension policies for upliftment of goat farmers following stall fed and extensive/grazing rearing system.
\end{abstract}

\section{Introduction}

The goat was the earliest ruminant to be domesticated. Goats had been associated with man in a symbiotic relationship for up to 10,000 years (Ensminger and Parker, 1986). This long association between goat and human indicates the variety of functions the goat can provide. Goats had been reported to be important to food and economic securities of developing regions for countless years, and their contributions to economic returns in developed countries has been rising as well (Sahlu and Goetsch, 2005). As per 20 livestock census (2019), Goat population of India and Punjab is 148.88 million and 3.48 
lakhs respectively. In $19^{\text {th }}$ livestock census, Goat population of India and Punjab was 135.17 million and 3.27 lakhs respectively (http://dadf.gov.in/sites/default/filess/BAHS\% 20\%28Basic\%20Animal\%20Husbandry\%20S tatistics-2019\%29.pdf). This indicates that there is increase in population of goats at both state and national level. In other words, more number of farmers are engaged in goat farming. Basically, two types of rearing system are prevalent for goats- Stall fed and extensive system. In Stall fed/intensive/zero grazing system, the goats are continuously kept under housing in confinement and are fed on manger. Stall fed rearing requires more labour and high cash input. But, there is the advantage of close supervision and control over the animals. In extensive/grazing system of rearing, goat farmer roam from one place to another along with their flocks and goat sustain on grazing. The knowledge about demographic profile parameters (age, sex, education, main occupation, family size, family type, land holding and category) can provide valuable information about the beneficiaries' goat farmers and can help in better planning and execution of extension programme. However, in Punjab state, the exhaustive and comprehensive study about stall fed and extensive rearing goat farmers is not there. So, the present study was planned to assess the demographic profile parameters and their interrelations for both stall fed and extensive rearing farmers.

\section{Material and Methods}

The present study was conducted in all the six different agro-climatic zones of Punjab, namely Sub mountain undulating zone (Zone I), Undulating plain zone (Zone II), Central plain zone (Zone III), Western plain zone (Zone IV), Western zone (Zone V) and Flood plain zone (Zone VI). Also, the goats farmers are divided in to two groups- Group I (Stall fed goat farmers, $\mathrm{n}=60$ ) and Group II
(Extensive rearing goat farmers, $n=60$ ). From each agro-climatic zone, 10 goat farmers belonging to both the groups were randomly selected. Thus, the total number of respondents was 120 . The goat farmers were personally interviewed with the help of prestructured and pre-tested interview schedule by visiting their farm at field level. The collected data were carefully examined for completeness and correctness before tabulation. For analysis, simple tabular techniques and appropriate statistical methods were employed by using SPSS version 20.0 for Frequency and Percentage analysis and Correlation coefficient analysis.

\section{Results and Discussion}

It is discussed under following subheads

\section{Distribution of Group I goat farmers according to demographic profile in different agro-climatic zones of Punjab}

Table 1 depicts that majority of goat farmers belonging to Group I in agro-climatic zones I, II, III, IV, V, VI and in overall Punjab belonged to age group of 31-60 years. Singh et al., 2020 also reported that in Punjab, most of the goat farmers $(62.50 \%)$ were between age group 31-60 years. However, Roy and Tiwari (2016) reported that in West Bengal and Uttar Pradesh, the mean age of the goat owners was around 41 years. All the goat farmers in present study were male. Singh et al., 2020 also reported that in Punjab, very few $(0.83 \%)$ goat farmers were female. Byaruhanga et al., 2015 also reported that in Uganda, majority (87\%) of household rearing goats were male. However, Raghavan and Raja (2012) reported that in Malabar region of Kerala, females are mainly engaged in goat rearing. The education level of a significant goat farmers is low. So, extension programmes should be organized after keeping in view their education level. The 
latest scientific practices and recommendations should be communicated to them according to their education level i.e. in simple, mother tongue, easily understandable language. The main occupation of most of the Group I goat farmers belonging to zone I, II, III, IV, V, VI and in overall Punjab was goat farming, followed by Labour/Service/ Business and then agriculture. However, Roy and Tiwari (2016) reported that in West Bengal and Uttar Pradesh, agriculture was the main occupation of the goat owners. Islam et al., 2018 reported that in Sylhet, Bangladesh, majority of the farmers $(59.33 \%)$ were labourer. Most of Group I goat farmers had medium to large family size and joint type family. A large number of goat farmers in Zone III and zone V were having land < Acres. It suggests entry of resource rich farmers in to goat farming. Also, a large number of Group I goat farmers in different zones belonged to Schedule caste and Backward caste.

\section{Distribution of Group II goat farmers according to demographic profile in different agro-climatic zones of Punjab}

It is clear from Table 2 that most of goat farmers of Group II in overall Punjab and in different agro-climatic zones were in age group of 31-60 years. All the goat farmers were male. Most of the goat farmers of Group II in all the zones were illiterate. Tanwar et al., 2008 also reported that in the tribal area of Udaipur district of Rajasthan, majority of the goat farmers were illiterate. Tudu and Roy (2015) also reported that in Nadia district of West Bengal, more than half of the goat keepers $(54 \%)$ were illiterate and percentage of women with primary, secondary and higher secondary were $20.66,19.33$, and 6 . The main occupation of Group II goat farmers is goat farming. Majority of group II goat farmers in Zone I, II, III, IV and V had joint families, while for zone VI, single type family was mostly observed. Majority of Group II farmers were reported to be landless. The Group II goat farmers did not owe land and are dependent on extensive rearing/grazing system.

\section{Distribution of goat farmers according to demographic profile in different rearing system}

A perusal of Table 3 and Figure 1 indicates that most of goat farmers of Group I and Group II were in age group of 31-60 years, followed by $\leq 30$ years and then $>60$ years. Tanwar et al., (2008) reported that in the tribal area of Udaipur district of Rajasthan, majority of the goat farmers belonged to 3150 years of age group. Also in Nathdwara, Vallabhnagar, Railmagra and Devgarh areas of Rajasthan the majority of goat rearers were reported to be belonging to middle age group (Sharma et al., 2007). However, Tudu and Roy (2015) reported that in Nadia district of West Bengal, maximum goat farmers were in the age group of $20-40$ years $(48 \%)$, followed by $0-20$ years $(24.66 \%), 40-60$ years and 60 years and above age groups represents $18 \%$ and $8.66 \%$. All the goat farmers of Group I and Group II were male. This suggests that goat farming in Punjab is predominantly done by male goat farmers. Although, goat is a small animal and it can be easily handled by women and children. But, women are not predominantly involved in goat farming due to social or other reason. The goat farming can play a pivotal role in women empowerment. So, there is dire need to conduct extension campaign to educate and encourage women farmer to adopt goat farming as it will empower them. Gamit et al., 2020 reported that in the Saurashtra region that majority (95.83\%) of heads of households were males, of which $44 \%$ were middle age (31-50). However, Sarmini et al., 2017 reported that in Vavuniya district of Sri Lanka, $59.1 \%$ of women were involved in goat farming. 
Table.1 Distribution of Group I goat farmers according to demographic profile in different agro-climatic zones of Punjab

\begin{tabular}{|c|c|c|c|c|c|c|c|c|}
\hline Attributes & Parameter & $\begin{array}{l}\text { Zone I } \\
(\mathrm{n}=10)\end{array}$ & $\begin{array}{c}\text { Zone II } \\
(\mathrm{n}=10)\end{array}$ & $\begin{array}{c}\text { Zone III } \\
(n=10)\end{array}$ & $\begin{array}{c}\text { Zone IV } \\
(\mathrm{n}=10)\end{array}$ & $\begin{array}{l}\text { Zone V } \\
(\mathrm{n}=10)\end{array}$ & $\begin{array}{c}\text { Zone VI } \\
(n=10)\end{array}$ & $\begin{array}{l}\text { Overall } \\
(\mathbf{n}=\mathbf{6 0})\end{array}$ \\
\hline \multirow[t]{3}{*}{ Age (years) } & $\leq 30$ years & $2(20)$ & $3(30)$ & $1(10)$ & $1(10)$ & $1(10)$ & $4(40)$ & $12(20.00)$ \\
\hline & $31-60$ & $7(70)$ & $6(60)$ & $8(80)$ & $8(80)$ & $8(80)$ & $5(50)$ & $42(70.00)$ \\
\hline & $>60$ & $1(10)$ & $1(10)$ & $1(10)$ & $1(10)$ & $1(10)$ & $1(10)$ & $6(10.00)$ \\
\hline \multirow[t]{2}{*}{ Sex } & Male & $10(100)$ & $10(100)$ & $10(100)$ & $10(100)$ & $10(100)$ & $10(100)$ & $60(100)$ \\
\hline & Female & $0(0)$ & $0(0)$ & $0(0)$ & $0(0)$ & $0(0)$ & $0(0)$ & $0(0)$ \\
\hline \multirow[t]{5}{*}{ Education } & Illiterate & $2(20)$ & $3(30)$ & $1(10)$ & $1(10)$ & $1(10)$ & $4(40)$ & $12(20.00)$ \\
\hline & Up to middle & $5(50)$ & $3(30)$ & $4(40)$ & $6(60)$ & $2(20)$ & $4(40)$ & $24(40.00)$ \\
\hline & High School & $3(30)$ & $4(40)$ & $5(50)$ & $3(30)$ & $7(70)$ & $2(20)$ & $24(40.00)$ \\
\hline & Higher secondary & $0(0)$ & $0(0)$ & $0(0)$ & $0(0)$ & $0(0)$ & $0(0)$ & $0(0)$ \\
\hline & Graduate and Postgraduate & $0(0)$ & $0(0)$ & $0(0)$ & $0(0)$ & $0(0)$ & $0(0)$ & $0(0)$ \\
\hline \multirow{3}{*}{$\begin{array}{l}\text { Main } \\
\text { occupation }\end{array}$} & Agriculture & $0(0)$ & $1(10)$ & $2(20)$ & $2(20)$ & $1(10)$ & $1(10)$ & $7(11.67)$ \\
\hline & Goat farming & $7(70)$ & $6(60)$ & $8(80)$ & $7(70)$ & $9(90)$ & $5(50)$ & $42(70.00)$ \\
\hline & Labour/Service/ Business & $3(30)$ & $3(30)$ & $0(0)$ & $1(10)$ & $0(0)$ & $4(40)$ & $11(18.33)$ \\
\hline \multirow[t]{3}{*}{ Family size } & Small $(\leq 4)$ & $3(30)$ & $3(30)$ & $1(10)$ & $1(10)$ & $0(0)$ & $4(40)$ & $12(20.00)$ \\
\hline & Medium (5-8) & $3(30)$ & $3(30)$ & $4(40)$ & $6(60)$ & $3(30)$ & $4(40)$ & $23(38.33)$ \\
\hline & Large $(>8)$ & $4(40)$ & $4(40)$ & $5(50)$ & $3(30)$ & $7(70)$ & $2(20)$ & $25(41.67)$ \\
\hline \multirow[t]{2}{*}{ Family type } & Single & $3(30)$ & $3(30)$ & $2(20)$ & $4(40)$ & $1(10)$ & $4(40)$ & $17(28.33)$ \\
\hline & Joint & $7(70)$ & $7(70)$ & $8(80)$ & $6(60)$ & $9(90)$ & $6(60)$ & $43(71.67)$ \\
\hline \multirow{4}{*}{ (Acres) } & Landless & $7(70)$ & $6(60)$ & $5(50)$ & $7(70)$ & $4(40)$ & $8(80)$ & $37(61.67)$ \\
\hline & $(<5)$ & $3(30)$ & $4(40)$ & $5(50)$ & $3(30)$ & $6(60)$ & $2(20)$ & $23(38.33)$ \\
\hline & $5-10$ & $0(0)$ & $0(0)$ & $0(0)$ & $0(0)$ & $0(0)$ & $0(0)$ & $0(0)$ \\
\hline & $>10$ & $0(0)$ & $0(0)$ & $0(0)$ & $0(0)$ & $0(0)$ & $0(0)$ & $0(0)$ \\
\hline \multirow[t]{4}{*}{ Category } & General & $3(30)$ & $2(20)$ & $3(30)$ & $3(30)$ & $4(40)$ & $3(30)$ & $18(30.00)$ \\
\hline & Schedule caste & $6(60)$ & $5(50)$ & $4(40)$ & $5(50)$ & $3(30)$ & $6(60)$ & $29(48.33)$ \\
\hline & Backward class & $1(10)$ & $3(30)$ & $3(30)$ & $2(20)$ & $2(20)$ & $1(10)$ & $12(20.00)$ \\
\hline & Other backward class & $0(0)$ & $0(0)$ & $0(0)$ & $0(0)$ & $1(10)$ & $0(0)$ & $1(1.67)$ \\
\hline
\end{tabular}

Figure in parenthesis indicate percentage 
Table.2 Distribution of Group II goat farmers according to demographic profile in different agro-climatic zones of Punjab

\begin{tabular}{|c|c|c|c|c|c|c|c|c|}
\hline Attributes & Parameter & $\begin{array}{l}\text { Zone I } \\
(\mathrm{n}=10)\end{array}$ & $\begin{array}{c}\text { Zone II } \\
(\mathrm{n}=10)\end{array}$ & $\begin{array}{c}\text { Zone III } \\
(\mathrm{n}=10)\end{array}$ & $\begin{array}{c}\text { Zone IV } \\
(\mathrm{n}=10)\end{array}$ & $\begin{array}{l}\text { Zone V } \\
(\mathrm{n}=10)\end{array}$ & $\begin{array}{c}\text { Zone VI } \\
(n=10)\end{array}$ & $\begin{array}{l}\text { Overall } \\
(\mathbf{n}=60)\end{array}$ \\
\hline \multirow[t]{3}{*}{ Age (years) } & $\leq 30$ years & $3(30)$ & $4(40)$ & $3(30)$ & $2(20)$ & $1(10)$ & $3(30)$ & $16(26.67)$ \\
\hline & $31-60$ & $5(50)$ & $4(40)$ & $6(60)$ & $6(60)$ & $6(60)$ & $5(50)$ & $32(53.33)$ \\
\hline & $>60$ & $2(20)$ & $2(20)$ & $1(10)$ & $2(20)$ & $3(30)$ & $2(20)$ & $12(20.00)$ \\
\hline \multirow[t]{2}{*}{ Sex } & Male & $10(100)$ & $10(100)$ & $10(100)$ & $10(100)$ & $10(100)$ & $10(100)$ & $60(100)$ \\
\hline & Female & $0(0)$ & $0(0)$ & $0(0)$ & $0(0)$ & $0(0)$ & $0(0)$ & $0(0)$ \\
\hline \multirow[t]{5}{*}{ Education } & Illiterate & $7(70)$ & $5(50)$ & $5(50)$ & $4(40)$ & $5(50)$ & $8(80)$ & $34(56.67)$ \\
\hline & Up to middle & $3(30)$ & $5(50)$ & $3(30)$ & $4(40)$ & $3(30)$ & $2(20)$ & $20(33.33)$ \\
\hline & High School & $0(0)$ & $0(0)$ & $2(20)$ & $2(20)$ & $2(20)$ & $0(0)$ & $6(10.00)$ \\
\hline & Higher secondary & $0(0)$ & $0(0)$ & $0(0)$ & $0(0)$ & $0(0)$ & $0(0)$ & $0(0)$ \\
\hline & Graduate and Postgraduate & $0(0)$ & $0(0)$ & $0(0)$ & $0(0)$ & $0(0)$ & $0(0)$ & $0(0)$ \\
\hline \multirow{3}{*}{$\begin{array}{l}\text { Main } \\
\text { occupation }\end{array}$} & Agriculture & $0(0)$ & $1(10)$ & $0(0)$ & $1(10)$ & $1(10)$ & $0(0)$ & $3(5.00)$ \\
\hline & Goat farming & $6(60)$ & $6(60)$ & $7(70)$ & $7(70)$ & $8(80)$ & $7(70)$ & $41(68.33)$ \\
\hline & Labour/Service/ Business & $4(40)$ & $3(30)$ & $3(30)$ & $2(20)$ & $1(10)$ & $3(30)$ & $16(26.67)$ \\
\hline \multirow[t]{3}{*}{ Family size } & Small $(\leq 4)$ & $4(40)$ & $4(40)$ & $3(30)$ & $2(20)$ & $1(10)$ & $6(60)$ & $20(33.33)$ \\
\hline & Medium (5-8) & $3(30)$ & $2(20)$ & $3(30)$ & $5(50)$ & $4(40)$ & $2(20)$ & $19(31.67)$ \\
\hline & Large $(>8)$ & $3(30)$ & $4(40)$ & $4(40)$ & $3(30)$ & $5(50)$ & $2(20)$ & $21(35.00)$ \\
\hline \multirow[t]{2}{*}{ Family type } & Single & $4(40)$ & $4(40)$ & $3(30)$ & $5(50)$ & $3(30)$ & $8(80)$ & $27(45.00)$ \\
\hline & Joint & $6(60)$ & $6(60)$ & $7(70)$ & $5(50)$ & $7(70)$ & $2(20)$ & $33(55.00)$ \\
\hline \multirow{4}{*}{$\begin{array}{l}\text { Land holdings } \\
\text { (Acres) }\end{array}$} & Landless & $9(90)$ & $8(80)$ & $9(90)$ & $10(100)$ & $9(90)$ & $9(90)$ & $54(90.00)$ \\
\hline & $(<5)$ & $1(10)$ & $2(20)$ & $1(10)$ & $0(00)$ & $1(10)$ & $1(10)$ & $6(10.00)$ \\
\hline & $5-10$ & $0(0)$ & $0(0)$ & $0(0)$ & $0(0)$ & $0(0)$ & $0(0)$ & $0(0)$ \\
\hline & $>10$ & $0(0)$ & $0(0)$ & $0(0)$ & $0(0)$ & $0(0)$ & $0(0)$ & $0(0)$ \\
\hline \multirow[t]{4}{*}{ Category } & General & $2(20)$ & $1(10)$ & $3(30)$ & $3(30)$ & $4(40)$ & $2(20)$ & $15(25.00)$ \\
\hline & Schedule caste & $6(60)$ & $5(50)$ & $4(40)$ & $5(50)$ & $4(40)$ & $6(60)$ & $30(50.00)$ \\
\hline & Backward class & $1(10)$ & $3(30)$ & $3(30)$ & $2(20)$ & $1(10)$ & $1(10)$ & $11(18.33)$ \\
\hline & Other backward class & $1(10)$ & $1(10)$ & $0(0)$ & $0(0)$ & $1(10)$ & $1(10)$ & $4(6.67)$ \\
\hline
\end{tabular}

Figure in parenthesis indicate percentage 
Table.3 Distribution of goat farmers according to demographic profile in different rearing system

\begin{tabular}{|c|c|c|c|c|}
\hline \multirow[t]{2}{*}{ Attributes } & \multirow[t]{2}{*}{ Parameter } & \multicolumn{2}{|c|}{ System of rearing } & \multirow[b]{2}{*}{ Overall $(n=120)$} \\
\hline & & Group I $(n=60)$ & Group II (n=60) & \\
\hline \multirow[t]{3}{*}{ Age (years) } & $\leq 30$ years & $12(20.00)$ & $16(26.67)$ & $28(23.33)$ \\
\hline & $31-60$ & $42(70.00)$ & $32(53.33)$ & $74(61.67)$ \\
\hline & $>60$ & $6(10.00)$ & $12(20.00)$ & $18(15.00)$ \\
\hline \multirow[t]{2}{*}{ Sex } & Male & $60(100)$ & $60(100)$ & $120(100)$ \\
\hline & Female & $0(0)$ & $0(0)$ & $0(0)$ \\
\hline \multirow[t]{5}{*}{ Education } & Illiterate & $12(20.00)$ & $34(56.67)$ & $46(38.33)$ \\
\hline & Up to middle & $24(40.00)$ & $20(33.33)$ & $44(36.67)$ \\
\hline & High School & $24(40.00)$ & $6(10.00)$ & $30(25.00)$ \\
\hline & Higher secondary & $0(0)$ & $0(0)$ & $0(0)$ \\
\hline & Graduate and Postgraduate & $0(0)$ & $0(0)$ & $0(0)$ \\
\hline \multirow[t]{3}{*}{ Main occupation } & Agriculture & $7(11.67)$ & $3(5.00)$ & $10(8.34)$ \\
\hline & Goat farming & $42(70.00)$ & $41(68.33)$ & $83(69.16)$ \\
\hline & Labour/Service/ Business & $11(18.33)$ & $16(26.67)$ & $27(22.50)$ \\
\hline \multirow[t]{3}{*}{ Family size } & Small $(\leq 4)$ & $12(20.00)$ & $20(33.33)$ & $32(26.67)$ \\
\hline & Medium (5-8) & $23(38.33)$ & $19(31.67)$ & $42(35.00)$ \\
\hline & Large $(>8)$ & $25(41.67)$ & $21(35.00)$ & $46(38.33)$ \\
\hline \multirow[t]{2}{*}{ Family type } & Single & $17(28.33)$ & $27(45.00)$ & $44(36.67)$ \\
\hline & Joint & $43(71.67)$ & $33(55.00)$ & $76(63.33)$ \\
\hline \multirow[t]{4}{*}{ Land holdings (Acres) } & Landless & $37(61.67)$ & $54(90.00)$ & $91(75.83)$ \\
\hline & $(<5)$ & $23(38.33)$ & $6(10.00)$ & $29(24.17)$ \\
\hline & $5-10$ & $0(0)$ & $0(0)$ & $0(0)$ \\
\hline & $>10$ & $0(0)$ & $0(0)$ & $0(0)$ \\
\hline \multirow[t]{4}{*}{ Category } & General & $18(30.00)$ & $15(25.00)$ & $33(27.50)$ \\
\hline & Schedule caste & $29(48.33)$ & $30(50.00)$ & $59(49.17)$ \\
\hline & Backward class & $12(20.00)$ & $11(18.33)$ & $23(19.17)$ \\
\hline & Other backward class & $1(1.67)$ & $4(6.67)$ & $5(4.16)$ \\
\hline
\end{tabular}

Figure in parenthesis indicate percentage 
Table.4 Correlation coefficient of different demographic parameters of Group I goat farmers

\begin{tabular}{|l|c|c|c|c|c|c|}
\hline & Age & Education & $\begin{array}{c}\text { Main } \\
\text { occupation }\end{array}$ & $\begin{array}{c}\text { Family } \\
\text { size }\end{array}$ & $\begin{array}{c}\text { Family } \\
\text { type }\end{array}$ & $\begin{array}{c}\text { Land } \\
\text { holding }\end{array}$ \\
\hline Age & 1 & $0.800^{* *}$ & $0.721^{* *}$ & $0.757^{* *}$ & $0.637^{* *}$ & $0.426^{* * *}$ \\
\hline Education & $0.800^{* *}$ & 1 & $0.586^{* *}$ & $0.956^{* *}$ & $0.712^{* *}$ & $0.797^{* *}$ \\
\hline $\begin{array}{l}\text { Main } \\
\text { occupation }\end{array}$ & $0.721^{* *}$ & $0.586^{* *}$ & 1 & $0.650^{* *}$ & $0.698^{* *}$ & 0.208 \\
\hline Family size & $0.757^{* *}$ & $0.956^{* *}$ & $0.650^{* *}$ & 1 & $0.769^{* *}$ & $0.818^{* *}$ \\
\hline Family type & $0.637^{* *}$ & $0.712^{* *}$ & $0.698^{* *}$ & $0.769^{* *}$ & 1 & $0.496^{* *}$ \\
\hline Landholding & $0.426^{* *}$ & $0.797^{* *}$ & 0.208 & $0.818^{* *}$ & $0.496^{* *}$ & 1 \\
\hline
\end{tabular}

(**) - Correlation is significant at the 0.01 level (2-tailed)

Table.5 Correlation coefficient of different demographic parameters of Group II goat farmers

\begin{tabular}{|l|c|c|c|c|c|c|}
\hline & Age & Education & $\begin{array}{c}\text { Main } \\
\text { occupation }\end{array}$ & $\begin{array}{c}\text { Family } \\
\text { size }\end{array}$ & $\begin{array}{c}\text { Family } \\
\text { type }\end{array}$ & $\begin{array}{c}\text { Land } \\
\text { holding }\end{array}$ \\
\hline Age & 1 & $0.444^{* *}$ & $0.770^{* *}$ & $0.625^{* *}$ & $0.601^{* *}$ & 0.196 \\
\hline Education & $0.444^{* *}$ & 1 & $0.527^{* *}$ & $0.736^{* *}$ & $0.670^{* *}$ & 0.232 \\
\hline $\begin{array}{l}\text { Main } \\
\text { occupation }\end{array}$ & $0.770^{* *}$ & $0.527^{* *}$ & 1 & $0.769^{* *}$ & $0.732^{* *}$ & 0.221 \\
\hline Family size & $0.625^{* *}$ & $0.736^{* *}$ & $0.769^{* *}$ & 1 & $0.829^{* *}$ & $0.397^{* *}$ \\
\hline Family type & $0.601^{* *}$ & $0.670^{* *}$ & $0.732^{* *}$ & $0.829^{* *}$ & 1 & $0.302^{*}$ \\
\hline Landholding & 0.196 & 0.232 & 0.221 & $0.397^{* *}$ & $0.302^{*}$ & 1 \\
\hline
\end{tabular}

(**) - Correlation is significant at the 0.01 level (2-tailed)

(*)-Correlation is significant at the 0.05 level (2-tailed)

Figure.1 Distribution of goat farmers according to age for different rearing system in Punjab

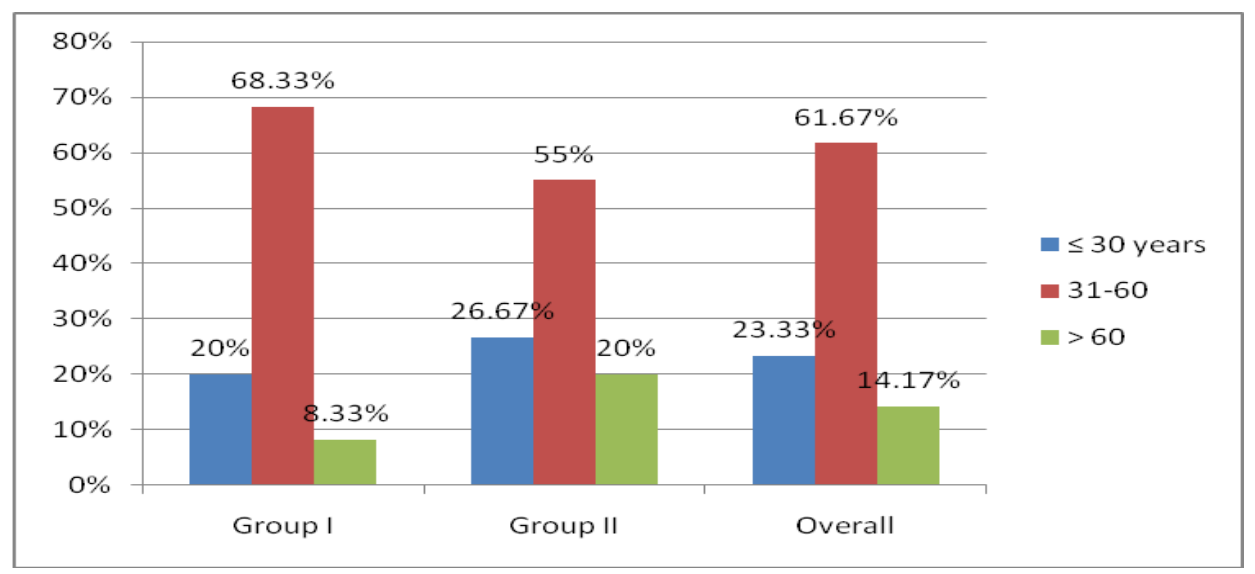


Fig.2 Distribution of goat farmers according to main occupation for different rearing system in Punjab

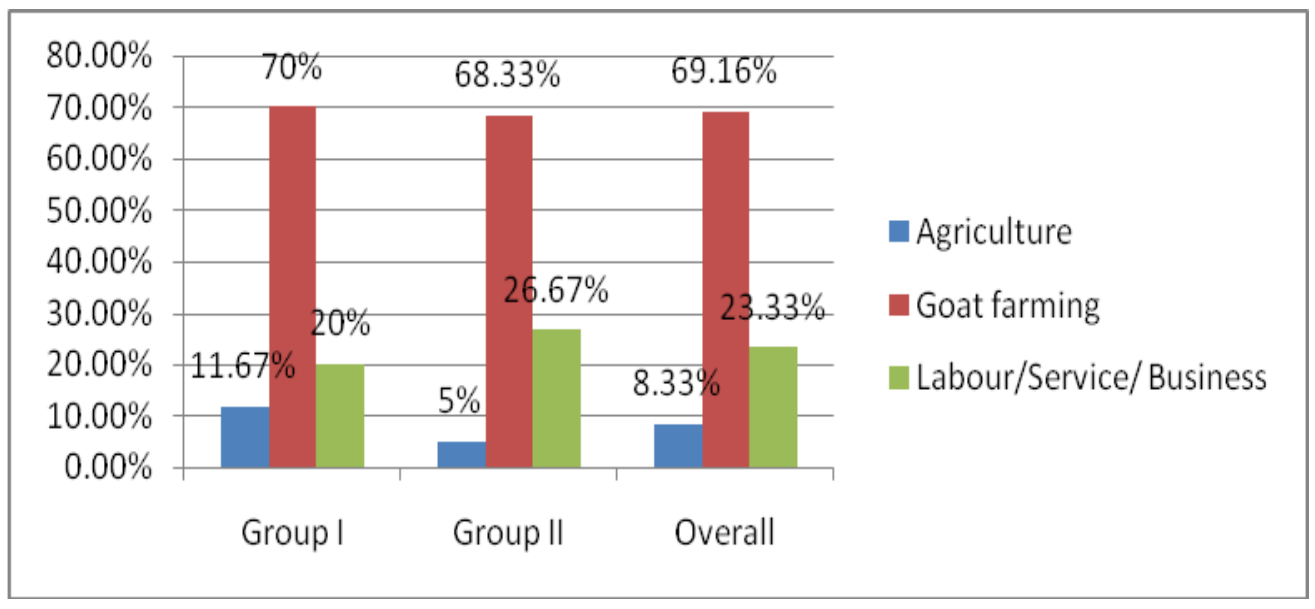

Fig.3 Distribution of goat farmers according to family size for different rearing system in Punjab

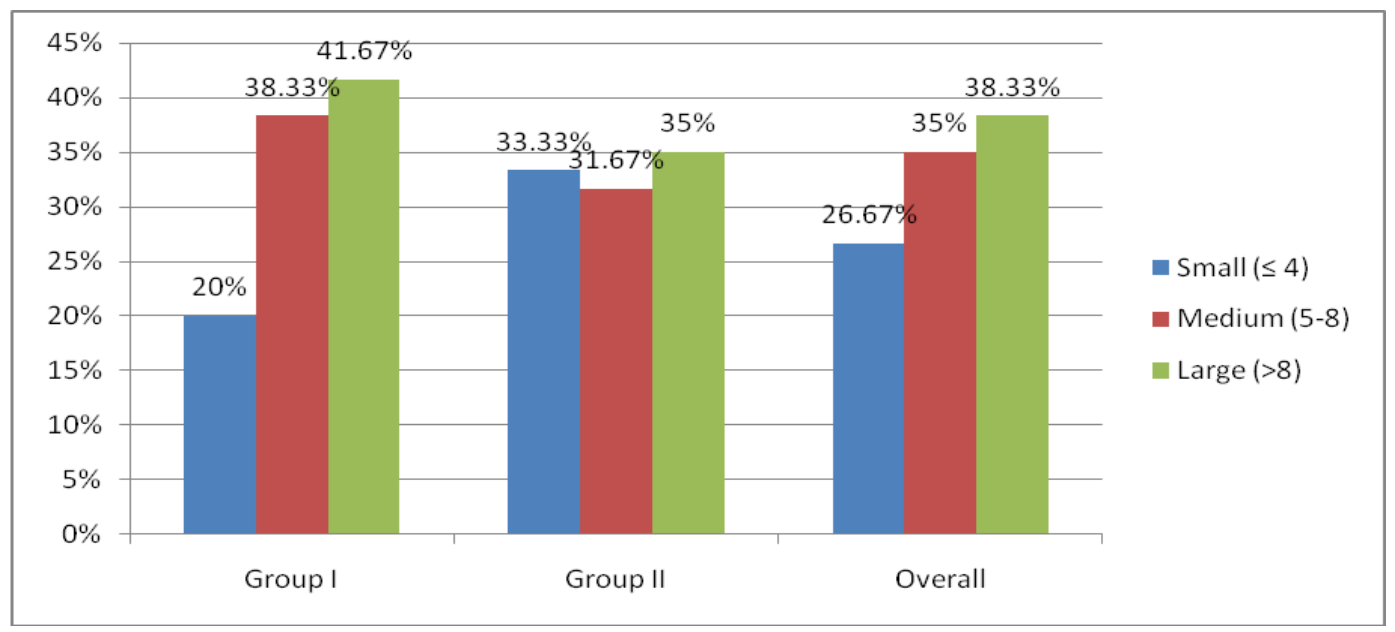

Fig.4 Distribution of goat farmers according to family type for different rearing system in Punjab

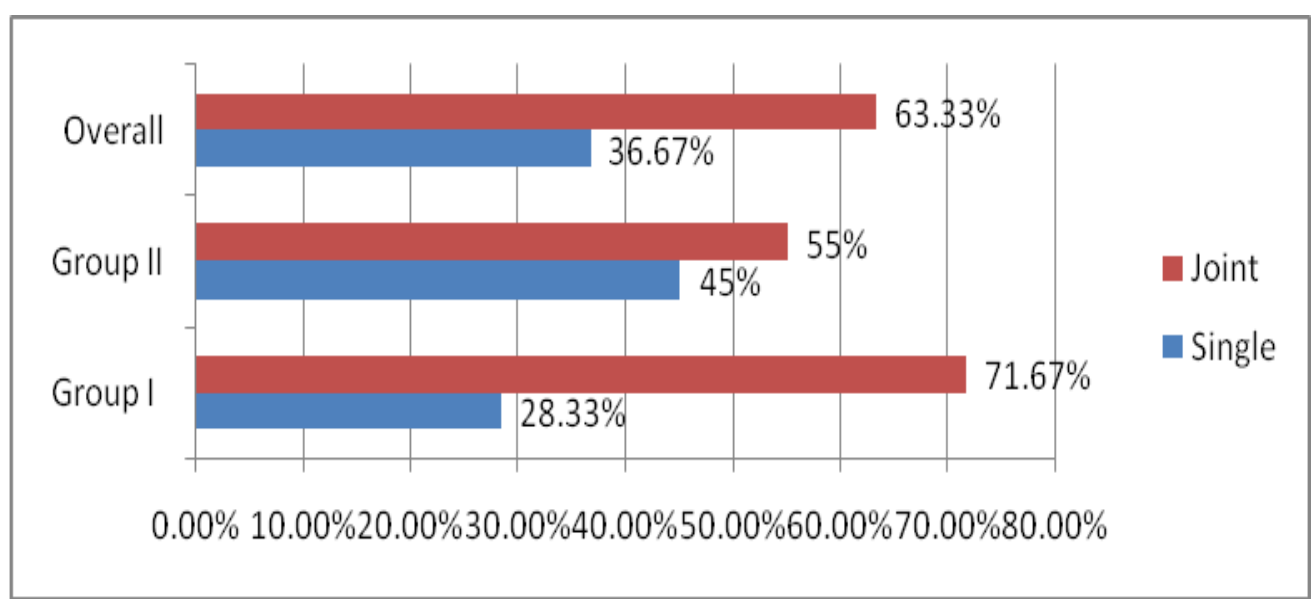


Fig.5 Distribution of goat farmers according to land holding for different rearing system in Punjab

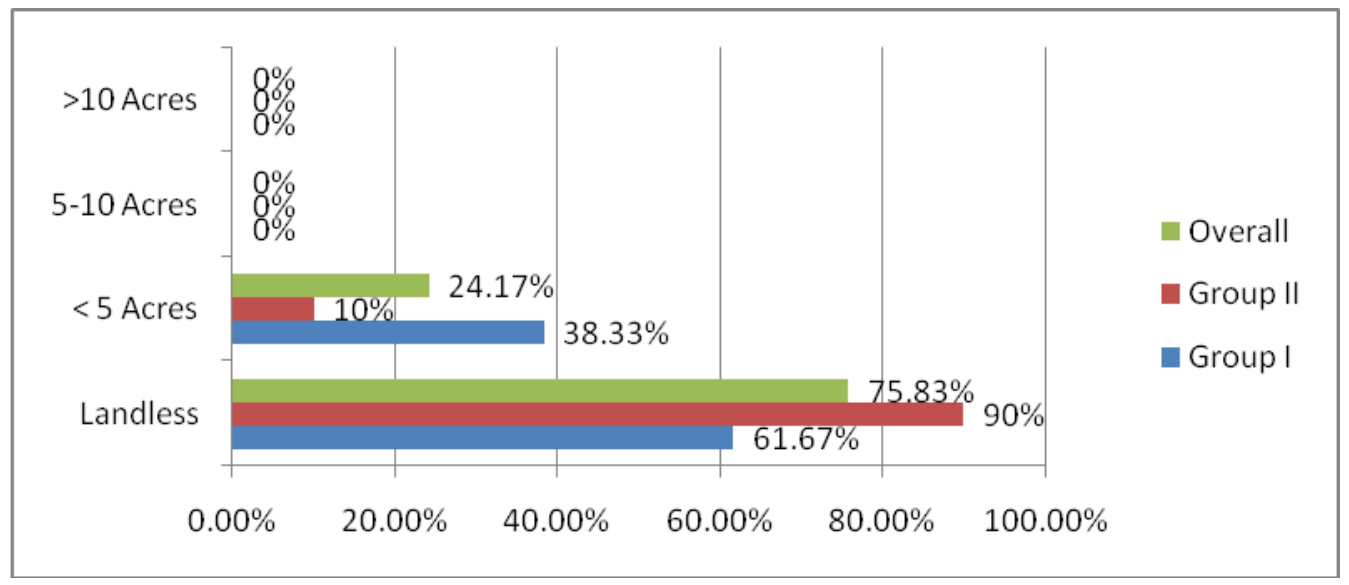

Bashir and Venkatachalapathy 2017 reported that in the northern part of Kerala, the participation of women in goat rearing and production was about $65 \%$. Kumar and Deoghare (2002) reported that in semi-arid parts of India, Goat rearing helps in the empowerment of poor rural women by providing them employment and to some extent financial autonomy. The education level of Group I goat farmers is more than that of Group II. It means that stall feeding is practiced by goat farmers having more educational level. The education level of 40 $\%$ Group I, $10 \%$ Group II and $25 \%$ goat farmers in overall Punjab was reported to be High School level. Raghavan and Raja (2012) also reported that in Malabar region of Kerala, $92 \%$ of the heads of the families were educated and $15 \%$ of them had high school level education and above. The main occupation in Group I, Group II and for overall Punjab Goat farmer is Goat farming, followed by Labour/Service/ Business and then agriculture (Figure 2). This indicates that farmers in both type of rearing system are primarily surviving on goat farming. This highlights the importance of adopting goat farming as main occupation instead of subsidiary occupation or side business. Singh et al., (2020) also reported that in main occupation of majority $(78.32 \%)$ of farmers engaged in rearing goats is goat farming in Punjab. A large number of goat farmers in Group I, II and in overall Punjab were having medium and large families (Figure 3). Arya and Chander (2000) also reported that the families which had more number of children were more inclined to keep goats as the children could be used for taking goats to grazing on fallow land, harvested fields, alongside roads and other uncultivated areas. In Group I, Group II and in overall Punjab, predominant family type is Joint family (Figure 4). It indicates the possibility of participation of other family members in effective operation of goat rearing. So, all the family members along with head of the family (which is predominantly involved in goat farming) should be made part of extension programme for upliftment of goat farmer. Figure 5 indicates that majority of goat farmers belonging to Group I, II and overall Punjab were landless. Rashmi (2010) also reported that in ravines Region of Etawah district of Uttar Pradesh, all the goat owners $(100 \%)$ were from landless and marginal land holding categories. Raghavan and Raja (2012) reported that in Malabar region of Kerala, most of goat farmers were marginal farmers with a land holding of $<50$ cents. Bashir and Venkatachalapathy (2017) reported that in the northern part of Kerala, goat farming was 
mainly dominated by small /marginal farmers and $90 \%$ of the goat farmers were having land holding less than 30 cents. Jayashree et al., 2014 reported that in Southern Karnataka, the landholdings of 1-2 acres and more than 2 acres were with $46.05 \%$ and $37.21 \%$ of the goat rearers respectively, while the remaining $(16.74 \%)$ goat rearers were landless labourers. A perusal of Table 3 also indicates that a large number of Group I, Group II and overall Punjab goat farmers belonged to Schedule caste, Backward caste and other backward caste. Kumar et al., 2015 also reported that most of the goat farmers belong to the backward and schedule castes in Western Uttar Pradesh.

\section{Correlation analysis between different demographic parameters}

Table 4 and 5 shows that the different demographic parameters such as age, education, main occupation, family size, family type and land holding are intercorrelated at $\mathrm{P}<0.01$ level for Group I farmers; and at $\mathrm{P}<0.05$ level and $\mathrm{P}<0.01$ level for Group II goat farmers. It means that more is the age, more is the education, main occupation is goat farming, more goat farmers with large, joint families and more is the landholding.

It can be concluded from foregoing that most of goat farmers following Stall fed and Extensive/Grazing rearing system were in age group of 31-60 years, male, with medium and large joint families were landless. Most of the farmers were adopting goat farming as main occupation. Also, the demographic parameters were inter-correlated significantly. The demographic profile of stall fed and extensive/grazing rearing system goat farmers should be taken in to consideration while formulating any extension policy for goat farmers following both type of rearing system.

\section{References}

Arya, H. P. S. and Chander, M. 2000. Goat production by landless and small scale farmers in North Indian plains. In Proc. Seventeenth Sympo. Int. Farming Systems Asso. Lake Buena Vista, Florida, USA. Conference.ifas.ufl.edu/ ifsa/papers/a/a10.doc.

Bashir, B. P. and Venkatachalapathy, R. T. 2017. Study on supply chains of goats in northern Kerala. Advances in Animal and Veterinary Sciences. 5(10): 395399.

Byaruhanga, C., Oluka, J. and Olinga, S. 2015. Socio-economic aspects of goat production in a rural agro-pastoral system of Uganda Universal Journal of Agricultural Research 3(6): 203-210.

Ensminger, M. E. and Parker, R. O. 1986. Sheep and Goat Science, $5^{\text {th }}$ Edn. Danville, Illinois: The Interstate Printers and Publishers Inc.

Gamit, V. V., Patbandha, T. K., Bariya, A. R., Gamit, K. C. and Patel, A. S. 2020. Socio-economic status and constrains confronted by goat and goat farmers in Saurashtra region. Journal of Entomology and Zoology Studies: 8(1):644-648.

Islam, M. A., Hossain, M. N., Chokraborti, S. S., Rahman, S., Tasnim, A. and Al Zabir, A. 2018. Socio-economic profile of goat rearing farmers and their management practices in Sylhet, Bangladesh. Journal of Agriculture and Ecology Research International 15(4):1-10.

Jayashree, R., Jayashankar, M. R., Nagaraja, C. S., Satyanarayana, K. and Shrikrishna, I. 2014. Goat rearing practices in Southern Karnataka. International Journal of Science, Environment 3(4): 1328-1335.

Kumar, S. and Deoghare, P. R. 2002. Goat rearing and rural poor: A case study in 
south-western semiarid zone of Uttar Pradesh. Annals of Arid Zone 41(1): 7984.

Kumar, S., Chauhan, H. S., Kide, W., Mayekar, A. J. 2015. Socio-economic profile of goat farmers in western Uttar Pradesh (India) Life Sciences International Research Journal 2(2): 43-46.

Raghavan, K. C. and Raja, T.V. 2012. Analysis on the socioeconomic status of the goat farmers of Malabar region of Kerala. Veterinary Research 5(4): 7476.

Rashmi. 2010. 'Goat rearing practices in ravines Region of Etawah district of Uttar Pradesh.' M.V.Sc. thesis, Indian Veterinary Research Institute, Izatnagar

Roy, R. and Tiwari, R. 2016. Socio-personal and Socio-economic profile of goat owners in India. Indian Journal of Extension Education 52 (3 \& 4):57-60.

Sahlu, T. and Goetsch, A. L. 2005. A foresight on goat research Small Ruminant Research 60: 7-12.

Sarmini, M., Premaratne, S. and Kalpana, S. 2017 Production and economic characteristics of goat management systems in Vavuniya district, Sri lanka in Proceedings of the 4th International Conference on Agriculture and Forestry
(ICOAF - 2017) organized by The International Institute of Knowledge Management (TIIKM), Colombo, Sri Lanka from 24th - 25th August, 2017 pp: 46-53.

Sharma, M. C., Pathodiya, O. P., Jingar, S. C. and Gaur, M. 2007. A study on socioeconomic status of goat rearers and adoption of management practices. Indian Journal of Small Ruminants 13(1): 75-83.

Singh, S., Kasrija, R., Singh, P., Singh, J. and Singla, M. 2020. An Appraisal of Demographic Parameters of Goat Farmers of Punjab. International Journal of Current Microbiology and Applied Sciences 9(01): 136-144.

Tanwar, P. S., Vaishanava, C. S. and Sharma, V. 2008. A study on socio-economic aspects of goat keepers and management practices prevailed in the tribal area of Udaipur district of Rajasthan. Indian Journal of Animal Research 42(1): 71-74.

Tudu, N. K. and Roy, D. C. 2015. Socioeconomic profile of women goat keepers and rearing challenges in goat in Nadia district of West Bengal. International Journal of Science, Environment and Technology 4(2): 331336.

\section{How to cite this article:}

Aman Deep Singh Dhaliwal, Rajesh Kasrija, Parminder Singh, Y. S. Jadoun and Sandeep Kaswan. 2020. Analyzing Demographic Profile of Stall Fed vis-à-vis Extensive Rearing Goat Farmers of Punjab. Int.J.Curr.Microbiol.App.Sci. 9(10): 2739-2749.

doi: https://doi.org/10.20546/ijcmas.2020.910.331 